Д.А. Дорогин

\title{
ОБСТОЯТЕЛЬСТВА, ИСКЛЮЧАЮЩИЕ УГОЛОВНУЮ ОТВЕТСТВЕННОСТЬ ЗА ПРЕСТУПЛЕНИЯ, СОВЕРШАЕМЫЕ ДОЛЖНОСТНЫМИ ЛИЦАМИ
}

Аннотация: Статья посвящена обстоятельствам, исключающим уголовную ответственность за преступления, совершаемые должностными лицами. Автором предлагается группировка посягательств, совершаемых должностными лицами. В статье представлен анализ ситуаций, в которых уголовная ответственность за данные деяния невозможна. К таковым относится несоответствие статуса субъекта тому или иному признаку должностного лица, вследствие чего в действиях лица отсутствует состав преступления, поскольку оно может быть совершено только специальным субъектом. Также к обстоятельствам, исключающим уголовную ответственность, можно причислить действия во исполнение приказа, крайняя необходимость, применение физической силы, оружия и специальных средств, парламентский индемнитет, провокация совершения преступления. Формулируются различная правовая природа парламентского индемнитета и иммунитета для целей исключения уголовной ответственности. В связи с последним обстоятельством особо выделяют правовые позиции Европейского Суда по правам человека. Автор рассматривает сложившуюся судебную практику по затронутому вопросу и предлагает пути решения отдельных правовых проблем.

Ключевые слова: исключение уголовной ответственности, должностное лицо, признаки специального субъекта, исполнение приказа, крайняя необходимость, применение оружия, парламентский индемнитет, иммунитет, провокация совершения преступления, ЕСПч

DOI: 10.7256/1994-1471.2014.3.9487

$\mathrm{O}$ собое место в уголовном праве занимает такая категория специальных субъектов преступлений, как должностные лица. В зависимости от целей той или иной отрасли права данный термин имеет различное содержание; применительно к уголовноправовой охране общественных отношений это понятие раскрывается в примечании 1 к ст. 285 УК $^{1}$.

Ещё в дореволюционный период виновником должностных преступлений признавали «всякое вменяемое лицо, которое, в силу лежащих на нём особых публично-правовых полномочий, находится к государственным, общественным и частным интересам в таком положении, которое даёт ему возможность причинять вред или ставить эти интересы в

Здесь и в дальнейшем имеется в виду Уголовный кодекс Российской Федерации (УК РФ), если не оговорено иное. Источник публикации: Уголовный кодекс Российской Федерации от 13.06.1996 г. № 63-Ф3 // Российская газета. 1996. 18 июня, 19 июня, 20 июня, 25 июня. опасность»². Данное высказывание представляется актуальным во все времена; на сегодняшний день преступления, совершаемые должностными лицами, также представляют собой объект повышенного внимания со стороны государства. Такие преступные деяния можно разделить на пять групп.

Первую из них образуют т.н. общие должностные преступления, т.е. преступления против государственной власти, интересов государственной службы и службы в органах местного самоуправления, которые законодатель выделил в самостоятельную группу общественно опасных посягательств, структурно обособив в тексте уголовного закона. К данным деяниям относится большинство преступлений гл. 30 УК (ст. 285, 285 ${ }^{1}$, $285^{2}, 285^{3}, 286,286^{1}, 287,289,290,292,292^{1}$, 293 УК).

\footnotetext{
См.: Ширяев В.Н. Взяточничество и лиходательство в связи с общим учением о должностных преступлениях. Ярославль, 1916. С. 565.
}

(C) Дорогин Дмитрий Александрович

* Ассистент кафедры уголовного права, Московский государственный юридический университет имени О.Е. Кутафина (МГЮА)

[silvestr117@yandex.ru]

123995, г. Москва, ул. Садовая-Кудринская, д. 9. 
Преступления, расположенные за пределами гл. 30 УК, однако субъектами которых выступают исключительно должностные лица, составляют вторую группу преступных деяний. Их можно назвать специальными, потому что они совершатся либо определёнными должностными лицами, либо в определённой сфере деятельности, образуя посягательства на иные ценности и блага, не входящие в содержание объекта общих должностных преступлений. К данной группе следует причислить преступления, предусмотренные ст. 140, ч. 3 ст. 141, ст. $149,169,170,185^{2}$, п. «а» ч. 3 ст. 194 , ст. $215^{1}$, п. «а» ч. 2 ст. $226^{1}$, п. «б» ч. 2 ст. $229^{1}$ УК. В этих статьях законодатель прямо указывает на совершение деяния именно должностным лицом. Сюда же относятся два преступления, составы которых включают признак совершения деяния лицом, занимающим государственную должность Российской Федерации либо субъекта Российской Федерации, а равно главой органа местного самоуправления (ч. 2 ст. 237 УК), или только лицом, занимающим государственную должность Российской Федерации либо субъекта Российской Федерации (ч. 2 ст. 354 УК).

Третья группа преступлений содержательно весьма близка ко второй, поскольку деяние запрещено уголовно-правовой нормой, не входящей в гл. 30 УК, и совершается оно только должностным лицом. Однако отличие заключается в том, что в статье непосредственно об этом не говорится; законодатель лишь устанавливает, что субъектом деяния выступает лицо, занимающее ту или иную должность, но анализ соответствующих полномочий позволяет сделать вывод о том, что данное лицо является именно должностным. В качестве примеров можно назвать противоправные деяния, совершаемые такими субъектами, как член избирательной комиссии (ст. 142 УК), следователь (ст. 300 УК), судья (ст. 305 УК) и др. К данной группе преступлений также следует отнести случаи, когда субъект в статье в принципе не называется, однако характер деяния таков, что оно может быть совершено только лицом, наделённым должностными полномочиями, например, незаконное привлечение к уголовной ответственности (ст. 299 УК), незаконные задержание, заключение под стражу или содержание под стражей (ст. 301 УК).

В четвёртую группу входят преступления, которые совершаются с использованием своего служебного положения. Их особенность состоит в том, что их субъектом может быть как должностное лицо, так и другой специальный субъект, в т.ч. даже специально не названный в уголовном законе, но использующий для совершения преступления своё служебное положение. Данное обстоятельство предусма- тривается законодателем в качестве квалифицирующего признака многих преступлений (например, в п. «В» ч. 2 ст. $127^{1}$, п. «Г» ч. 3 ст. 146, ч. 3 ст. 159 , ч. 3 ст. 209 , п. «а» ч. 2 ст. 241 УК). В двух деяниях - нарушении равенства прав и свобод человека и гражданина (ст. 136 УК) и вмешательстве в осуществление избирательной комиссией, комиссией референдума её полномочий (ч. 3 ст. 141 УК) - данному признаку придано значение конструктивного.

Наконец, пятую группу образуют преступления, ответственность за которые наступает на общих основаниях, т.е. эти деяния могут совершаться в равной мере как должностными лицами, так и любыми другими категориями лиц, в т.ч. и простыми гражданами. К таковым можно отнести все общеуголовные преступления.

Применительно к тем общественно опасным деяниям, которые совершаются должностными лицами с использованием их служебного положения, т.е. в механизме совершения которых для нарушения общественных отношений используются именно соответствующие публичные функции, можно говорить о специфических обстоятельствах, исключающих уголовную ответственность за то или иное посягательство, совершённое должностным лицом.

К таковым, в первую очередь, относится отсутствие признаков должностного лица как специального субъекта преступления, которое делает невозможным наступление уголовную ответственность за данное деяние и лишь в отдельных случаях - при наличии к тому оснований - может служить основанием для уголовной ответственности по другой статье (как правило, содержащей состав общеуголовного преступления).

В частности, одним из спорных вопросов отсутствия признаков специального субъекта является совершением лицом тех или иных действий (бездействия) в связи с выполнением им обязанностей должностного лица временно или по специальному полномочию. Очевидно, что лицо должно нести ответственность как должностное лишь за те действия, которые были совершены именно в период исполнения им соответствующих функций. Однако в соответствии с правовой позицией Верховного Суда РФ если лицо было назначено на ту или иную должность с нарушением установленных законом требований, его действия всё равно следует квалифицировать как должностное преступление ${ }^{3}$. Безусловно, такой подход спо-

См.: Постановление Пленума Верховного Суда РФ от 16.10.2009 г. № 19 «О судебной практике по делам о злоупотреблении должностными полномочиями и о превышении должностных полномочий» (п. 6) // Российская газета. 2009. 30 октября. 
собствует привлечению к ответственности лиц, фактически причинивших тот или иной вред, однако представляется, что подобное разъяснение противоречит принятым правилам квалификации преступлений, касающихся требования надлежащей «включённости» субъекта в систему нарушаемых им общественных отношений, в связи с чем несоблюдение требований к назначению лица на должность следовало бы рассматривать как обстоятельство, исключающее его уголовную ответственность в качестве специального субъекта.

Споры возникают и при толковании такого признака должностного лица, как выполнение им организационно-распорядительных функций. В соответствии с общепринятой трактовкой эти функции должностного лица включают в себя полномочия по принятию решений, имеющих юридическое значение и влекущих юридические последствия. Это означает, что они наделяют других лиц правами и обязанностями, изменяют их объём либо прекращают их, т.е. порождают, изменяют или прекращают правоотношения.

Судебная практика относит субъекта к должностным лицам, если его действия или решения влекут юридически значимые последствия, в т.ч. «возможные и достаточно отдалённые», а также опосредованные последующими действиями иных лиц ${ }^{4}$. В то же время трактовка полномочий лица по принятию решений, имеющих юридическое значение и влекущих юридически значимые последствия, не должна быть чрезмерно широкой. В частности, не признан должностным лицом заведующий общежитием, потому что его функции являются чисто техническими и не влекут за собой правовых последствий ${ }^{5}$.

Дискуссионным является вопрос о том, могут ли быть причислены к должностным (по признаку выполнения организационно-распорядительных функций) лица, которые производят те или иные конкретные действия, сами по себе не влекущие юридически значимых последствий, однако выступающие основанием для принятия другими лицами (однозначно признаваемыми должностными) юридически значимых действий.

В этом вопросе рациональной представляется следующая позиция. Если действия и решения рядового работника носят рекомендательный характер, то его полномочия не имеют юридического значения, а значит, не являются организационно-распорядительными. Однако

См.: БВС РФ. 2002. № 8; Определение Верховного Суда РФ от 10.11.2002 г. № 46-О02-102 // СПС «КонсультантПлюс». ведомственными нормативными правовыми актами могут устанавливаться случаи, когда подобные решения налагают на других лиц обязанности по совершению тех или иных юридически значимых действий, что уже следует признавать организационно-распорядительными функциями ${ }^{6}$.

Однако большее признание получила противоположная точка зрения - «рядовые работники» во всяком случае не могут признаваться должностными лицами ${ }^{7}$, что, конечно, исключает их уголовную ответственность. По этому же пути идёт и судебная практика. В частности, Верховный Суд РФ указал, что не являются должностными лицами те субъекты, которые выполняют профессиональные или технические обязанности, не относящиеся к организационно-распорядительным или административно-хозяйственным функциям ${ }^{8}$.

В то же время нередки ситуации, когда на некоторых специалистов государственных органов или учреждений, выполняющих сугубо профессиональные или технические обязанности, в связи с осуществлением этих обязанностей или наряду с ними возлагается также выполнение функций управленческого характера. Поэтому для целей уголовно-правовой охраны общественных отношений должностными лицами могут признаваться и такие работники. Прежде всего, это касается врачей и преподавателей 9 . Характерно, что именно на эти категории лиц было специально указано в постановлении Пленума Верховного Суда РФ от 16.10.2009 г. № 19 «О судебной практике по делам о злоупотреблении должностными полномочиями и о превышении должностных полномочий» (далее - постановление Пленума Верховного Суда РФ от 16.10.2009 г. № 19) (выдача медицинским работником листка временной нетрудоспособности, выставление оценок членом государственной экзаменационной (аттестационной) комиссии ${ }^{10}$.

6 См.: Бриллиантов А.В., Яни П.С. Должностное лицо: организационно-распорядительные функции // Законность. 2010. № 6. С. 14.

См.: Шнитенков А. Выполнение преподавателем профессиональных и должностных функций // Уголовное право. 2001. № 4; Грошев А.В. Ответственность за взяточничество. Краснодар, 2008. С. 158.

8 См.: Постановление Пленума Верховного Суда РФ от 10.02.2000 г. № 6 «О судебной практике по делам о взяточничестве и коммерческом подкупе» (п. 5) // Российская газета. 2000. 23 февраля.

См., напр.: БВС РФ. 2000. № 8; БВС РФ. 2001. № 1; БВС РФ. 2002. № 8.

10 См.: Постановление Пленума Верховного Суда РФ от 16.10.2009 г. № 19 «О судебной практике по делам о злоупотреблении должностными полномочиями и о превышении должностных полномочий» (п. 4). 
Однако подобная постановка вопроса требует чёткого разграничения профессиональных и организационно-распорядительных функций конкретного специалиста. В этой связи показательным является следующее дело. Так, врач-хирург Г. был осуждён за то, что путём вымогательства получал от больных взятки за производство хирургических операций. Осматривая больных и устанавливая, что им нужна операция, Г. сообщал им об этом и заранее получал вознаграждение. По делу было указано, что Г. полномочиями, делающими его должностным лицом, не обладал, поскольку постановка диагноза, обследование больного и проведение операции являются производственно-профессиональными обязанностями медицинского работника, но не организационно-распорядительными функциями, свойственными должностному лицу ${ }^{11}$.

Уголовная ответственность за преступление, совершаемое должностным лицом, исключается, если лицо, не являясь должностным, выполняет организационно-распорядительные или административно-хозяйственные функции в иных организациях. Следует учитывать, что в соответствии с гражданским законодательством к коммерческим организациям относятся государственные и муниципальные унитарные предприятия, поэтому лица, выполняющие в них соответствующие функции, не могут признаваться должностными, что исключает их уголовную ответственность за соответствующие деяния.

Помимо отсутствия признаков специального субъекта существуют и иные обстоятельства, исключающие уголовную ответственность за преступления, совершаемые должностными лицами, на которых в силу их определённой специфики стоит остановиться отдельно. Общие правила в этом аспекте проблемы сформулированы в постановлении Пленума Верховного Суда РФ от 16.10.2009 г. № 19.

В частности, получил решение непростой вопрос о наказуемости действий должностных лиц во исполнение обязательного для них приказа. Если незаконность такого приказа осознавалась его адресатом, оно несёт ответственность на общих основаниях. При этом вышестоящее должностное лицо, отдавшее незаконный приказ, уголовной ответственности также подлежит; его действия следует квалифицировать как организацию либо подстрекательство к совершению соответствующего преступления.

В случае когда исполнитель приказа по обстоятельствам дела не осознавал его незакон-

\footnotetext{
11 См.: БВС СССР. 1982. № 4. С. 30-31.
}

ность, его уголовная ответственность исключается. Верховный Суд РФ также подчеркнул, что отдавшее приказ должностное лицо должно в такой ситуации нести ответственность именно как исполнитель преступления ${ }^{12}$.

Высшая судебная инстанция обошла стороной вопрос о неисполнении заведомо незаконного приказа. Он приобретает особую актуальность в свете относительно недавнего появления в уголовном законе специальной статьи, предусматривающей ответственность за умышленное неисполнение приказа сотрудником органа внутренних дел (ст. $286^{1}$ УК). В силуч. 2 ст. 42 УК уголовная ответственность в таких ситуациях исключается.

Также разъяснено, что обычная для дел о должностных преступлениях (в первую очередь, о превышении должностных полномочий (ст. 286 УК)) ссылка виновного на «интересы дела» может быть принята судом во внимание, только то или иное деяние совершено должностным лицом в условиях крайней необходимости, условия правомерности которой необходимо оценивать по правилам ст. 39 УК. Прежде всего, речь идёт о невозможности устранения опасности правоохраняемым интересам другими средствами, не связанными с причинением вреда ${ }^{13}$.

Что касается разграничения правомерных действий должностных лиц, применяющих в соответствии с законодательными предписаниями физическую силу, оружие и специальные средства, а также посягательств, связанных с преступным их применением (прежде всего, речь идёт о превышении должностных полномочий с применением оружия или специальных средств - п. «б» ч. 3 ст. 286 УК), то для этого необходимо учитывать основания, условия и пределы соответствующих действий, которые предусмотрены целым рядом нормативных правовых актов ${ }^{14}$.

12 См.: Постановление Пленума Верховного Суда РФ от 16.10.2009 г. № 19 «О судебной практике по делам о злоупотреблении должностными полномочиями и о превышении должностных полномочий» (п. 14).

13 См.: Постановление Пленума Верховного Суда РФ от 16.10.2009 г. № 19 «О судебной практике по делам о злоупотреблении должностными полномочиями и о превышении должностных полномочий» (п. 13).

14 См., напр.: Закон Российской Федерации от 21.07.1993 года № 5473-1 «Об учреждениях и органах, исполняющих уголовные наказания в виде лишения свободы»; Федеральный закон от 15.07.1995 года № 103Ф3 «О содержании под стражей подозреваемых и обвиняемых в совершении преступлений»; Федеральный закон от 06.02.1997 года № 27-Ф3 «О внутренних войсках Министерства внутренних дел Российской Федерации»; Федеральный закон от 21.07.1997 года № 118-ФЗ «О судебных приставах»; Федеральный закон от 07.02.2011 г. № 3-Ф3 «О полиции». 
Важным обстоятельством, исключающим уголовную ответственность должностных лиц, выступает парламентский индемнитет как гарантия деятельности законодательных (представительных) органов власти государства. Уголовный закон не содержит норм об индемнитете, но соответствующие предписания представлены в нормативных правовых актах иной отраслевой принадлежности применительно ко всем уровням публичной власти в Российской Федерации.

Так, согласно ч. 6 ст. 19 Федерального закона от 08.05.1994 г. № 3-Ф3 «0 статусе члена Совета Федерации и статусе депутата Государственной Думы Федерального Собрания Российской Федерации» член Совета Федерации и депутат Государственной Думы Федерального Собрания Российской Федерации не могут быть привлечены к уголовной или административной ответственности за высказывание мнения или выражение позиции при голосовании в соответствующей палате Федерального Собрания Российской Федерации и другие действия, соответствующие статусу члена Совета Федерации и статусу депутата Государственной Думы, в том числе по истечении срока их полномочий ${ }^{15}$.

Аналогичные правила действуют также на региональном и муниципальном уровнях в отношении депутатов законодательных (представительных) органов государственной власти субъектов Российской Федерации (ч. 3 ст. 13 Федерального закона от 06.10.1999 г. № 184-Ф3 «Об общих принципах организации законодательных (представительных) и исполнительных органов государственной власти субъектов Российской Федерации») ${ }^{16}$, а также депутатов, членов выборных органов местного самоуправления и выборных должностных лиц местного самоуправления (ч. 9 ст. 40 ФЗ «Об общих принципах организации местного самоуправления в Российской Федерации») ${ }^{17}$.

Индемнитет можно рассматривать в качестве обстоятельства, исключающего уголовную ответственность, поскольку в данном случае устраняется такой признак преступления, как наказуемость. Приведённое положение представляет

15 См.: Федеральный закон от 08.05.1994 г. № 3-Ф3 «О статусе члена Совета Федерации и статусе депутата Государственной Думы Федерального Собрания Российской Федерации» // Российская газета. 1999. 8 июля.

16 См.: Федеральный закон от 06.10.1999 г. № 184-Ф3 «Об общих принципах организации законодательных (представительных) и исполнительных органов государственной власти субъектов Российской Федерации» // Российская газета. 1999. 19 октября.

17 См.: Федеральный закон от 06.10.2003 г. № 131-Ф3 «Об общих принципах организации местного самоуправления в Российской Федерации» // Российская газета. 2003. 8 октября. собой опосредованное процессуальными средствами (ч. 4 ст. 448 Уголовно-процессуального кодекса Российской Федерации ${ }^{18}$ ) правило, изначально содержащееся в различных нормативных правовых актах, т.е. легально предусмотренное вне рамок уголовного закона специальное предписание, делающее невозможным наступление уголовной ответственности.

От индемнитета необходимо отличать иммунитет отдельных категорий должностных лиц, который выступает одним из основных элементов данного статуса и важной гарантией деятельности соответствующих субъектов. Применительно к депутатам федерального парламента Конституционный Суд РФ указал, что иммунитет не является личной привилегией, но носит публично-правовой характер, призвана служить публичным интересам, обеспечивая повышенную охрану законом личности парламентария в силу осуществляемых им государственных функций, ограждая его от необоснованного преследования, способствуя беспрепятственной деятельности парламентария и тем самым - парламента, их самостоятельности и независимости ${ }^{19}$.

Таким образом, иммунитет не может означать освобождения того или иного должностного лица от уголовной ответственности; он лишь призван служить процессуальной гарантией нормального функционирования государственных органов и органов местного самоуправления. Поэтому нельзя относить иммунитет к обстоятельствам, исключающим уголовную ответственность.

Всё большую актуальность и распространение приобретает такое обстоятельство, исключающее уголовную ответственность, как провокация совершения преступления. Оно не закреплено в российском законодательстве, но выработано в практике Европейского Суда по правам человека (далее - ЕСПЧ). Действия тайных агентов публичной власти, как правило, провоцируют совершение таких деяний, как незаконный оборот наркотиков, сбыт поддельных денег и, что представляет интерес для целей противодействия преступлениям должностных лиц, получение взятки. По ряду дел, в т.ч. и применительно к Российской Феде-

\footnotetext{
18 См.: Уголовно-процессуальный кодекс Российской Федерации от 18.12.2001 г. № 174-Ф3 // Российская газета. 2001. 22 декабря.

19 См.: Постановление Конституционного Суда РФ от 20.02.1996 г. № 5-П «По делу о проверке конституционности положений частей первой и второй статьи 18, статьи 19 и части второй статьи 20 Федерального закона от 8 мая 1994 года «О статусе депутата Совета Федерации и статусе депутата Государственной Думы Федерального Собрания Российской Федерации»» (п. 1) // Российская газета. 1996. 29 февраля.
} 
рации, ЕСПЧ было сформулировано несколько важных правовых позиций.

В соответствии с толкованием Конвенции о защите прав человека и основных свобод ${ }^{20}$, данным ЕСПЧ, действия тайных агентов публичной власти, представляющие собой подстрекательство к совершению преступления, исключают уголовную ответственность лица. Разумеется, ЕСПЧ не использует сам термин «исключение уголовной ответственности», но такое значение данного обстоятельства вытекает из формулируемых по делу выводов.

Так, по делу «Ваньян против Российской Федерации» была сформулирована следующая правовая позиция: если преступление было предположительно спровоцировано действиями тайных агентов публичной власти и ничто не предполагает, что оно было бы совершено и без какого-либо вмешательства, то эти действия уже не являются деятельностью тайного агента и представляют собой подстрекательство к совершению преступления ${ }^{21}$.

Дальнейшую конкретизацию условия, при которых провокация совершения преступления исключает уголовную ответственность лица, получили в решении по делу «Худобин против Российской Федерации». Так, было установлено, что хотя у заявителя не было криминального прошлого, у него имелись соответствующие контакты, что и было использовано сотрудниками правоохранительных органов. ЕСПЧ подчеркнул, что «в то время как в связи с ростом организованной преступности, несомненно, требуется принятие соответствующих мер, право на справедливое отправление правосудия, тем не менее, занимает такое значимое место <...>, что им нельзя жертвовать в целях выгоды». В самом деле, у внутригосударственных органов не было достаточных причин, чтобы подозревать заявителя в причастности к преступной деятельности; совсем наоборот, по-видимому, милицейская операция была направлена на поимку не лично заявителя, но любого лица, которое бы согласилось совершить соответствующие действия ${ }^{22}$.

20 См.: Конвенция о защите прав человека и основных свобод (заключена в г. Риме 04.11.1950 г.) // Бюллетень международных договоров. 2001. № 3. Конвенция ратифицирована Федеральным законом от 30.03 .1998 г. № 54-Ф3 «О ратификации Конвенции о защите прав человека и основных свобод и Протоколов к ней».

21 См.: Постановление Европейского Суда по правам человека от 15.12.2005 г. по делу «Ваньян (Vanyan) против Российской Федерации» (Жалоба № 53203/99) // Бюллетень ЕСПЧ. 2006. № 7.

22 См.: Постановление Европейского Суда по правам человека от 26.10.2006 г. по делу «Худобин (Khudobin) против Российской Федерации» (Жалоба № 59696/00) // Бюллетень ЕСПЧ. 2007. № 11.
Ещё одним важным аспектом проблемы провокации является вопрос о моменте, когда правоохранительные органы должны узнать о возможном совершении преступления и «включиться» в этот процесс. В частности, ситуация, дающая ответ на этот вопрос, имела место в деле «Раманаускас против Литвы». Так, к заявителю, который работал прокурором, в частном порядке обратилось лицо, оказавшееся служащим специального антикоррупционного подразделения полиции. Служащий предложил заявителю взятку за обещание содействовать в оправдании третьего лица. Тот первоначально отказался, но после многократного повторения подобного предложения, согласился. Полицейский уведомил своё начальство, и заместитель генерального прокурора санкционировал провокацию взятки.

Согласно позиции ЕСПЧ национальные власти не могут быть освобождены от ответственности за действия полицейских только благодаря ссылке на то, что те действовали «от своего имени». Более того, уполномочив полицейского симулировать дачу взятки и освободив его от какой-либо уголовной ответственности, власти одобрили предварительную стадию операции задним числом и использовали её результаты. Действия полицейского и знакомство с заявителем вышли за пределы пассивного контроля существующей криминальной деятельности, поскольку все встречи заявителя и полицейского имели место по инициативе последнего.

Кроме того, ЕСПЧ сформулировал ещё один важный вывод: признание в преступлении, совершённом в результате подстрекательства, не устраняет ни самого подстрекательства, ни его последствий. Поэтому не может быть принят вывод о том, что, поскольку вина заявителя установлена, вопрос о наличии какого-либо внешнего влияния на него не имеет значения ${ }^{23}$.

Некое обобщение критериев разграничения правомерных действий в рамках оперативно-розыскного мероприятия и провокации было сделано в относительно недавнем деле «Банникова против Российской Федерации». В решении вопроса, оставались ли государственные представители, осуществляющие негласную деятельность, в рамках «преимущественно пассивного» поведения или вышли за них, действуя как агенты-провокаторы, ЕСПЧ применил материальный критерий провокации. Он предполагает: оценку того, имелись ли объективные подозрения в причастности заявительницы к преступной деятельности;

23 См.: Постановление Европейского Суда по правам человека от 05.02.2008 г. по делу «Раманаускас (Ramanauskas) против Литвы» (Жалоба № 74420/01) // Бюллетень ЕСПЧ. 2008. № 8. 
«включились» ли тайные агенты в преступные действия или спровоцировали их; и подвергали ли они заявительницу давлению, с тем, чтобы она совершила преступление ${ }^{24}$.

Правовым позициям ЕСПЧ по вопросам провокации совершения преступления корреспондируют и некоторые положения отечественного уголовного права. Так, в постановлении Пленума Верховного Суда РФ от 10.02.2000 г. № 6 «0 судебной практике по делам о взяточничестве и коммерческом подкупе» говорится, что не является провокацией взятки проведение предусмотренного законодательством оперативно-розыскного мероприятия в связи с проверкой заявления о вымогательстве взятки ${ }^{25}$.

Сходное разъяснение представлено и в другом документе высшей судебной инстанции: результаты оперативно-розыскного мероприятия могут быть положены в основу приговора, если они получены в соответствии с требованиями закона и свидетельствуют о наличии у виновного умысла на незаконный оборот запрещённых предметов, сформировавшегося независимо от деятельности сотрудников оперативных подразделений, а также о проведении лицом всех подготовительных действий, необходимых для совершения противоправного деяния ${ }^{26}$.

Следует согласиться с мнением В.С. Комиссарова и П.С. Яни, что «благодаря решениям ЕСПЧ, воспринятым высшим судебным органом России, провокационно-подстрекательскую деятельность сотрудников правоохранительных органов следует рассматривать в качестве нового, пока не отражённого в гл. 8 УК РФ обстоятельства, исключающего преступность деяния, совершённого лицом, в отношении которого эта деятельность осуществлялась» ${ }^{27}$.

В настоящее время приведённые правовые позиции стали использоваться в отечественной судебной практике по конкретным делам. Так, Б., представляющий интересы 000 «Магнат», обратился к М. по вопросу строительства либо приобретения объекта недвижимости

24 См.: Постановление Европейского Суда по правам человека от 04.11.2010 г. по делу «Банникова (Bannikova) против Российской Федерации» (Жалоба № 18757/06) // Российская хроника Европейского Суда. 2011. № 4.

25 См.: Постановление Пленума Верховного Суда РФ от 10.02.2000 г. № 6 «О судебной практике по делам о взяточничестве и коммерческом подкупе» (п. 25).

26 См.: Постановление Пленума Верховного Суда РФ от 15.06.2006 г. № 14 «О судебной практике по делам о преступлениях, связанных с наркотическими средствами, психотропными, сильнодействующими и ядовитыми веществами» (п. 14) // Российская газета. 2006. 28 июня.

Комиссаров В.С., Яни П.С. Провокационно-подстрекательская деятельность в отношении должностного лица как обстоятельство, исключающее ответственность за получение взятки // Законность. 2010. № 9. С. 8. с последующей эксплуатацией. М., действуя с целью получения взятки, сообщил Б., что окажет тому содействие в получении земельного участка или здания, находящегося в муниципальной собственности, при условии получения незаконного денежного вознаграждения. В последующем М. позвонил Б. и потребовал, чтобы тот передал водителю автомобиля марки «Тойота-Карина» денежные средства в сумме 6000 долларов США, предназначавшиеся ему в качестве взятки. В этот же день сын М., находясь в автомобиле марки «Тойота-Карина», действуя по поручению и в интересах своего отца, получил от Б. деньги в сумме 6000 долларов США в качестве взятки, предназначавшейся М., после чего был задержан сотрудниками милиции.

Суд пришёл к выводу о том, что в действиях М. отсутствует состав преступления, и оправдал его. При проведении оперативно-розыскных мероприятий нарушены требования ст. 5 Федерального закона от 12.08.1995 г. № 144-Ф3 «Об оперативно-розыскной деятельности» ${ }^{28}$. Судом установлено, что свидетель Б. выступал представителем 000 «Магнат», реквизиты которого использовались для проведения оперативнорозыскных мероприятий в отношении М., и без ведома руководства данного общества.

Орган, осуществляющий оперативно-розыскную деятельность, спровоцировал получение М. денег. Отсутствуют доказательства того, что до вмешательства Б. у правоохранительных органов были основания подозревать М. в получении взяток. Простое заявление сотрудника милиции А. в суде о том, что РУБОП располагал секретной информацией соответствующего характера, которая, к тому же, не была предоставлена суду, не может быть принято во внимание. Оперативно-розыскной орган не ограничился пассивным фиксированием предполагаемой преступной деятельности М., но инициировал проведение оперативнорозыскного мероприятия с участием Б., хотя ничего не предполагало, что деяние было бы совершено без его вмешательства ${ }^{29}$.

Таким образом, уголовная ответственность за преступления, совершаемые должностными лицами, исключается целым рядом обстоятельств, учёт и правильное применение которых весьма значимы для соблюдения законности, а также обеспечения прав и законных интересов личности, общества и государства.

28 См.: Федеральный закон от 12.08.1995 года № 144Ф3 «Об оперативно-розыскной деятельности» // Российская газета. 1995. 18 августа.

29 См.: Кассационное определение Судебной коллегии по уголовным делам Верховного Суда РФ от 21.02.2008 г. № 9-О08-4 // СПС КонсультантПлюс. 


\section{Библиография}

1. Бриллиантов А.В., Яни П.С. Должностное лицо: организационно-распорядительные функции // Законность. 2010. № 6.

2. Грошев А.В. Ответственность за взяточничество. Краснодар, 2008.

3. Комиссаров В.С., Яни П.С. Провокационно-подстрекательская деятельность в отношении должностного лица как обстоятельство, исключающее ответственность за получение взятки // Законность. 2010. № 9.

4. Ширяев В.Н. Взяточничество и лиходательство в связи с общим учением о должностных преступлениях. Ярославль, 1916.

5. Шнитенков А. Выполнение преподавателем профессиональных и должностных функций // Уголовное право. 2001. № 4.

\section{References}

1. Brilliantov A.V., Yani P.S. Dolzhnostnoe litso: organizatsionno-rasporyaditel'nye funktsii // Zakonnost'. 2010. № 6.

2. Groshev A.V. Otvetstvennost' za vzyatochnichestvo. Krasnodar, 2008.

3. Komissarov V.S., Yani P.S. Provokatsionno-podstrekatel'skaya deyatel'nost' v otnoshenii dolzhnostnogo litsa kak obstoyatel'stvo, isklyuchayushchee otvetstvennost' za poluchenie vzyatki // Zakonnost'. 2010. № 9.

4. Shiryaev V.N. Vzyatochnichestvo i likhodatel'stvo v svyazi s obshchim ucheniem o dolzhnostnykh prestupleniyakh. Yaroslavl', 1916.

5. Shnitenkov A. Vypolnenie prepodavatelem professional'nykh i dolzhnostnykh funktsii // Ugolovnoe pravo. 2001. № 4.

Материал поступил в редакцию 20 сентября 2013 г. 